\title{
An Early Warning Model for Technical Trading Indicators
}

\section{Kutluk Kagan Sumer}

Department of Econometrics, Faculty of Economics, Istanbul University, Istanbul, Turkey E-mail:kutluk@istanbul.edu.tr

Received June 14th, 2014; revised July 12th, 2014; revised August 10th, 2014

Copyright (C) 2015 Kutluk Kagan Sumer. This is an open access article distributed under the Eurasian Academy of Sciences License, which permits unrestricted use, distribution, and reproduction in any medium, provided the original work is properly cited.

\begin{abstract}
In this study, the technical indicators are used in forecasting whether stock prices will rise, fall or will be constant at the following day. The indicators are generated by taking into account the daily stock returns. If the daily stock returns are positive, the indicator is coded as " +1 "; if the daily stock returns are constant, the indicator is coded as " 0 " and at least if the daily stock returns are negative, the indicator is coded as " -1 ". These indicator values express the dependent vari-able of ordered choice models which independent variables are technical indicators. The ordered choice models are ap-plied to all of the stocks of ISE (Istanbul Stock Exchange).
\end{abstract}

Keywords: Stock Exchange; ISE; Technical Analysis; Technical Indicators; Early Warning; Ordered Choice

JEL: C25,C35,G15,G1

\section{INTRODUCTION}

The computation and interpretation of the technical indicators take place according to the methods described in the methodology. With the computation of the daily indicator value "NSI", which represents a conclusion value as dependent variable, the individual parameters of the respective technical indicators of a share with the technical indicators of the one day lagged are determined.

With a rising NSI (New Stock Indicator) the indicator value $(+1)$ was assigned to the shares, which were consulted in the model category three for the computation of the new indicator value "NSI", the shares with a constant "NSI" the indicator value $(0)$ and the shares with a falling "NSI" the indicator value (-1). During the dissolution this model was used for the dependent variables and their categorization the Ordered Choice model, whereby lining the variable $(-1),(0)$ and $(+1)$ the use of this model up put close.

The Ordered Choice methodology is used among other things with the determination by economic cycles:

How did the prices develop in the past period $\mathrm{P}_{\mathrm{t}}$ ? 
What for a price history is expected in the coming period $\mathrm{P}_{\mathrm{t}}^{*} ?^{1}$

King, Nerlove, Ottenwaelter and Oudiz have in their work:

- $\quad \mathrm{P}_{\mathrm{t}}^{*}$ as conditionally distributed regarded and with that adaptive expactations model for $\mathrm{P}_{\mathrm{t}-\mathrm{q}}{ }^{*}$ and $\mathrm{P}_{\mathrm{t}}$ compared

- $\mathrm{P}_{\mathrm{t}}^{*}$ as conditionally distributed regarded and with the extrapolative models for $\mathrm{P}_{\mathrm{t}-\mathrm{q}}{ }^{*}, \mathrm{P}_{\mathrm{t}}$ compared.

A general error correction mechanism is used derived by using $\Delta \mathrm{P}_{\mathrm{t}}{ }^{*} . \mathrm{E}\left(\mathrm{P}_{\mathrm{t}}\right)$ represents thereby the variable for $\Delta \mathrm{P}_{\mathrm{t}}{ }^{*}$ for changes of expectation, is "trichotomous" and takes the following values (Table 1):

$$
\begin{array}{ll}
\Uparrow & \text { Rising } \\
\Rightarrow & \text { Constant } \\
\Downarrow & \text { Falling }
\end{array}
$$

\begin{tabular}{|l|l|l||l|}
\hline $\mathrm{P}_{\mathrm{t}}^{*} \backslash \mathrm{P}_{\mathrm{t}+1} *$ & $\Uparrow$ & $\Rightarrow$ & $\Downarrow$ \\
\hline$\Uparrow$ & $=$ & + & + \\
\hline$\Rightarrow$ & - & $=$ & + \\
\hline$\Downarrow$ & - & - & $=$ \\
\hline
\end{tabular}

Table-1: Values of $\mathrm{P}_{t} * \mathrm{P}_{\mathrm{t}+1}$

The computation of the Ordered Logit and Ordered Probit models is based on the Maximum Likelihood method.

Like already with the technical analysis on the basis the conclusion values of the past periods the future development of the conclusion values is mentioned estimated. With this kind of the estimation the conclusion values of share shows dependence and it becomes repetitive share price history.

The following acceptance of the model is at the basis of technical models:

- The share prices are determined by supply and demand.

- Supply and demand occur by external factors i.e. inflation, interest rates, exchange rates etc.

- Easy share price fluctuations are neglected; do recognize trends with the share prices.

- The changes at trends due to changes at supply and demand.

The changes at supply and demand are responsible for the fact that it comes to the changes of trends pursued by the share prices. The technical analysts call the application of the technical analysis instead of fundamental analysis according to following reasons:

- The fundamental analysis is time-consuming and dependent to its user's economic basic knowledge. In contrast to it simple basic knowledge is sufficient for the application of the technical analysis. For this reason by small investors the technical analysis is preferred. The confrontation of the investors with similar formations and indicators leads to the fact that you display homogeneous actions and because of these actions supply and demand are affected.

\footnotetext{
${ }^{1}$ GOURIEROUX Christian (2000): Econometrics of Qualitative Dependent Variables; Cambridge University Press; S. 141-142
} 
- The fundamental analysis helps to become attentive on shares with low prices and to make plans possible into this security. The success of such a plan depends on the fact that the remaining investors become attentive to these shares and their offers thus increase, so that it comes by it to share price increases.

- Users of the technical analysis are not on those balances and success estimations, which are however not set up after according to tax law principles the actual costing and yield structure to again-reflect, instructed.

- The results of the fundamental analysis illustrate the central to long-term price change. With the technical analysis it is possible to use short term data investment decisions.

- Speculative price history is not illustrated with the fundamental analysis. The technical analysis proved with speculative shares as particularly sensitive to analyze method. Speculations lead to the revaluation of shares, whereby the financial indicators at force of expression lose.

\section{METHODOLOGY: ORDERED CHOICE MODELS}

The many of the Multinomial Choice variables are automatically arranged. In the literature the following examples are called: ${ }^{2}$

Security evaluations ${ }^{3}$

Results of sample tests

Public opinion polls

Dispatching from military personnel to place qualifications after qualification level

Election results with certain programs

In requirement taken insurance level by consumers: no partial, full demand Occupation: Full employment, part-time work, unemployment.

At all these cases, although the result is discrete, the Multinomial Logit and Probit models would fail to the dependent variable with ordinal nature. Usually regression analyses are into the opposite direction. If one regards for example the result of sample tests or a public opinion poll, then arises: if the effect with $0,1,2,3$ or 4 is coded, the linear involution represents the difference between 4 and 3, equal the difference between 3 and 2 .

The Ordered Probit and Logit of models finds a strong use as an analysis stand (Zavoina and McElvey, 1975). The Ordered Probit model is set up, like the Binomial Probit model, for a latent involution.

The initial equation reads:

$y^{*}=\beta^{\prime} x+\epsilon$

\footnotetext{
${ }^{2}$ GREENE, William H. (2000): Econometric analysis; Prentice Hall; S. 875-887

${ }^{3}$ BACKUS, David (1998): Discrete-time models of bond pricing; National Bureau of Economic Research, 
Usually $y *$ the non-observed variable represents. It represents a form of the censorship. One observes:

$$
\begin{aligned}
& y=0 \text { if } y^{*} \leq 0 \\
& =1 \text { if } \quad 0<y^{*} \leq \mu_{1} \\
& =2 \text { if } \quad \mu_{1}<y^{*} \leq \mu_{2}
\end{aligned}
$$

Those $\mu$ are unknown parameters, also $\beta$ become estimated. During the view of a public opinion poll we can see that all asked persons have their own feeling intensity, those from the measurable factors $\mathrm{x}$ and did not determine not observed factors $\in$ depend. They can answer to the questions with their own $y^{*}$, if this is permitted. With five possible answers for example given, they select that one, which corresponds to its feelings during the given question at most. 4

Assumed $\in$ is normal distributed with constant variance. From the same reasons as in the binomial probit model (special case $J=1$ ), becomes the average value and the variance of $\in$ to 0 and 1 normalizes. The model can be distributed also with a logistically distributed disturbance. This trivial modification of the formula does not seem to make a real difference in practice.

The following probabilities result in the case of normal distribution:

$$
\begin{aligned}
& \operatorname{Prob}(\mathrm{y}=0)=\Phi\left(-\beta^{\prime} \mathrm{x}\right) \\
& \operatorname{Prob}(\mathrm{y}=1)=\Phi\left(\mu_{1}-\beta^{\prime} \mathrm{x}\right)-\Phi\left(-\beta^{\prime} \mathrm{x}\right) \\
& \operatorname{Prob}(\mathrm{y}=2)=\Phi\left(\mu_{2}-\beta^{\prime} \mathrm{x}\right)-\Phi\left(\mu_{1}-\beta^{\prime} \mathrm{x}\right)
\end{aligned}
$$

For all positive probabilities is the result

$0<\mu_{1}<\mu_{2}<\ldots<\mu_{\mathrm{J}-1}$

\footnotetext{
${ }^{4}$ MITTELHAMMER Ron C. , JUDGE George G. und MILLER Douglas J. (2000). Econometric foundations; Cambridge Univ. Press; S:563-598.
} 


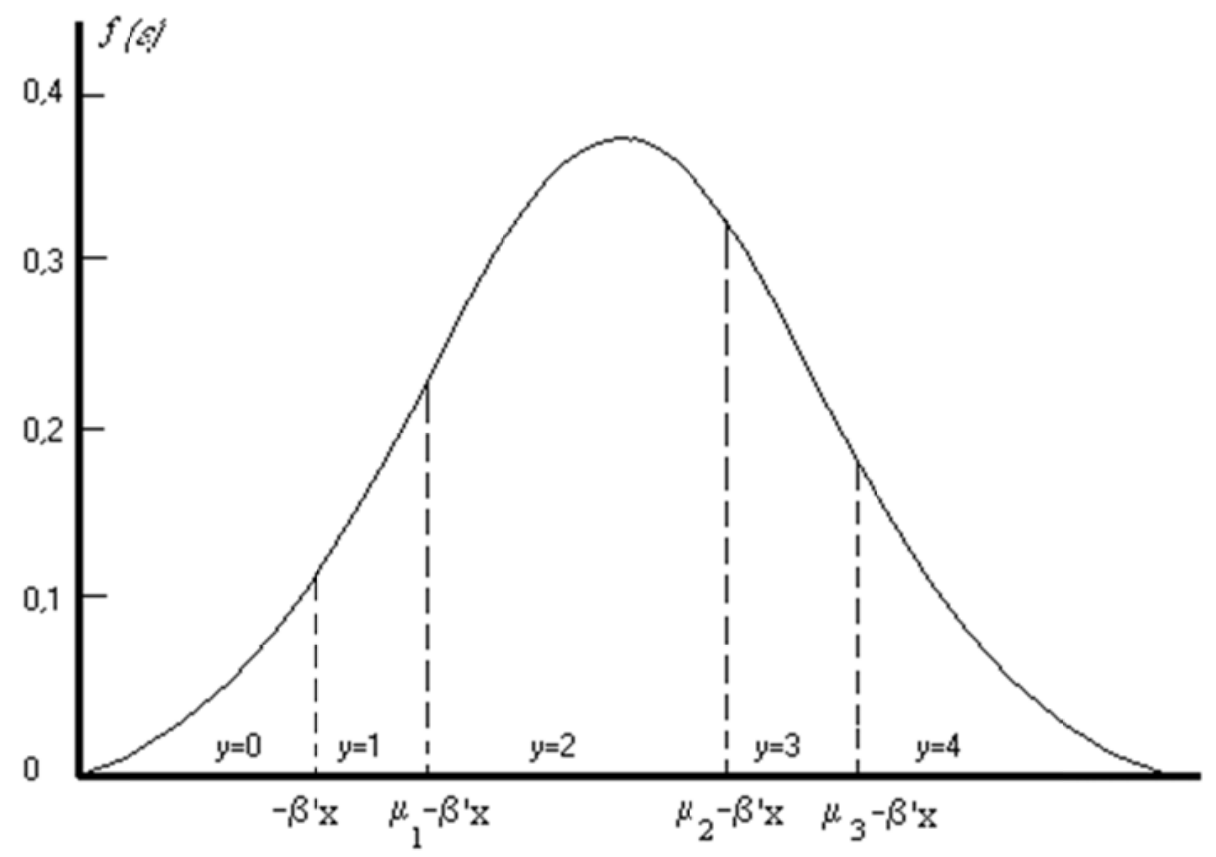

Figure 1: Probabilities with Ordered probit models

Figure 1 shows the effects of the structure. It is a generalized case of the probit of model represented above. The log Likelihood function and its derivative can be easily determined. The optimization takes place as usual.

The marginal effects of the Regressors $\mathrm{x}$ are not alike for the determined probability and the coefficients. For example there are three categories. The model exhibits an unknown border parameter. The three probabilities read:

$$
\begin{aligned}
& \operatorname{Prob}(y=0)=1-\Phi\left(-\beta^{\prime} x\right) \\
& \operatorname{Prob}(y=1)=\Phi\left(\mu-\beta^{\prime} x\right)-\Phi\left(-\beta^{\prime} x\right)
\end{aligned}
$$

The marginal effects of the change of Regressors for the three probabilities read: ${ }^{5}$

$$
\begin{aligned}
& \frac{\partial \operatorname{Pr} o b[y=0]}{\partial x}=-\phi\left(\beta^{\prime} x\right) \beta \\
& \frac{\partial \operatorname{Pr} o b[y=1]}{\partial x}=\left[\phi\left(-\beta^{\prime} x\right)-\phi\left(\mu-\beta^{\prime} x\right)\right] \beta \\
& \frac{\partial \operatorname{Pr} o b[y=2]}{\partial x}=\phi\left(\mu-\beta^{\prime} x\right) \beta
\end{aligned}
$$

\footnotetext{
${ }^{5}$ GREENE, William H. (2000). Econometric analysis; Prentice Hall; S:877.
} 


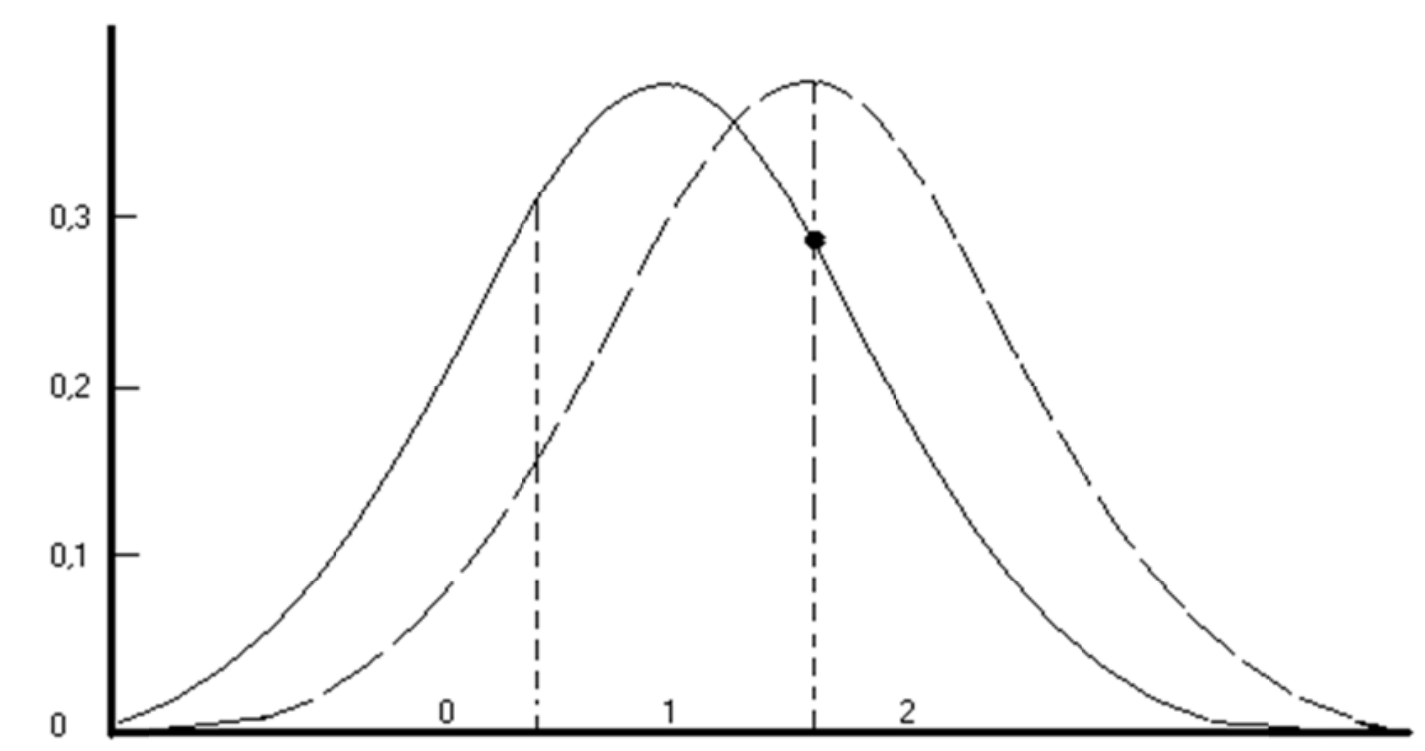

Figure 2: Effects of the change of $\mathrm{x}$ with forecast probabilities

Figure 2 shows the effect of the change of Regressors. The probability distribution of $y$ and $y$ $*$ is represented in the pulled through curve. An increase of $x$, during $\beta i$ and $\mu$ to be kept constant, is to the right, represented as broken curve equal a shift of the distribution. The effect of the shift is a concentration on those completely left cell.

With the acceptance that $\beta$ for this $\mathrm{x}$, must $\operatorname{Prob}(\mathrm{y}=0)$ is positive sink. Alternatively to the previous expression, the derivative of $\operatorname{Prob}(y=0)$ has the contrary sign for $\beta$. With a similar logic the change knows case ] the same sign with $\operatorname{Prob}(y=2)[$ or $\operatorname{Prob}(y=J)$ generally how $\beta$ have. On the assumption that it is positive, it shifts the probability into the right cell. Which passed it with the middle cell unclearly, depends on the two densities. Generally, in dependence to the signs of the coefficients, only the changes of $\operatorname{Prob}(y=0)$ and $\operatorname{Prob}(y=J)$ are unclear. In summary it can be said that the interpretation of the coefficients must be accomplished in this model very carefully. With the models represented above it acts up to now around to few clear model. Without an appropriate number of computations the kind of the interpretation of coefficients is not clear in Ordered Probit models. ${ }^{6}$

\section{TECHNICAL INDICATOR VARIABLES AND MODELS}

In the table, Ordered probit is used for the indicators as presented into the individual models as argument. A new indicator "NSI R" (NSI REAL) is computed, which represents the daily conclusion values of the individual shares. The indicator "NSI C" (NSI calculated) is determined with the help of down stated the formula for all at the IMKB noting 250 shares and from it a "NSI E" (NSI Estimated) is derived.

\footnotetext{
${ }^{6}$ GREENE, William H. (2000): Econometric analysis; Prentice Hall; S. 878
} 


$$
\begin{aligned}
& N S I \mathrm{E}_{t}=\beta_{C C I} \cdot C C I_{t-1}+\beta_{\text {OSILATOR }} \text { OSILATOR } \text { OS-1 }+\beta_{P V T} . P V T_{t-1}+\beta_{\text {ROC }} \cdot \text { ROC }_{t-1} \\
& +\beta_{\text {VOLUME }} \text { VOLUME } E_{t-1}+\beta_{\text {MACD }} \cdot \text { MACD }_{t-1}+\beta_{\text {MOMENRTUM }} \cdot \text { MOMENTUM }{ }_{t-1} \\
& \beta_{\text {RSI }} \cdot R S I_{t-1}+\beta_{\text {VOLOSIL }} \cdot \text { VOLOSIL }_{t-1}+\beta_{\text {WILLIAMS }} \text {.WILLIAMS } S_{t-1}+\beta_{\text {NSIE }(-1)} . N S I E_{t-1}
\end{aligned}
$$

The following technical indicators were consulted for the models (Table 2):

\begin{tabular}{llll}
\hline CCI & Commodity Channel Index & OSILATOR & Stochastic Oscillator \\
PVT & Price Volume Trend & ROC & Rate of IChange \\
VOLUME & Acted quantity & MACD & Macd \\
MOMENTUM & Momentum & RSI & Relative Strenght Index \\
VOLOSIL & Volume Oscillator & WILLIAMS & Williams \% R \\
NSI $(-1)$ & NSI one day lagged & & \\
LR Index (Pseudo-R & & \\
\hline
\end{tabular}

Table-2: Technical Indicators variables

In the Ordered Probit tables under the parameter estimated values the standard errors are bold indicated. For those shares without parameter estimated values, the parameter estimations are not efficient.

The estimated parameter values of the technical indicators state above for all shares that computed. They represent the argument in each case in the individual models. From the dependent variable "NSI R" is determined the indicator "NSI C" and derived from it with the help of that far down aforementioned method the indicator "NSI E". This indicator can accept the "NSI R" with the comparison with values the values $(+1)$ for rising, $(0)$ for constant and (1) for falling prices.

With the computation of the estimated parameter values the Ordered Choice models (Ordered Logit models and Ordered Probit models) is used. In the theoretical part the Ordered Choice methodolgy is described in detail. During the derivative of the indicator "NSI P" from the indicator "NSI E" the following method is used:

$Y_{i}^{*}=\beta x^{\prime}+\varepsilon$

$$
\begin{aligned}
& Y_{i}=\left\{\begin{array}{lll}
-1 & \text { when } & Y_{i}^{*} \leq \gamma_{1} \\
0 & \text { when } & \gamma_{1}<Y_{i}^{*} \leq \gamma_{2} \\
1 & \text { when } & \gamma_{2}<Y_{i}^{*}
\end{array}\right. \\
& \operatorname{Pr}\left(Y_{i}=-1 \mid x_{i}, \beta, \gamma\right)=\phi\left(\gamma_{1}-x^{\prime} \beta\right) \\
& \operatorname{Pr}\left(Y_{i}=0 \mid x_{i}, \beta, \gamma\right)=\phi\left(\gamma_{2}-x^{\prime} \beta\right)-\phi\left(\gamma_{1}-x^{\prime} \beta\right) \\
& \operatorname{Pr}\left(Y_{i}=1 \mid x_{i}, \beta, \gamma\right)=1-\phi\left(\gamma_{2}-x^{\prime} \beta\right) \\
& \ell(\beta, \gamma)=\sum_{i \ni Y i=-1} \log \left(\operatorname{Pr}\left(Y_{i}=-1 \mid x_{i}, \beta, \gamma\right)\right)+\sum_{i \ni Y=0} \log \left(\operatorname{Pr}\left(Y_{i}=0 \mid x_{i}, \beta, \gamma\right)\right)+\sum_{i \ni Y i=1} \log \left(\operatorname{Pr}\left(\mathbf{Y}_{i}=1 \mid x_{i}, \beta, \gamma\right)\right)
\end{aligned}
$$


The estimated parameter values are determined with the help of the equation (1) stated above. In the equation (2) $\gamma_{1}$ and $\gamma_{2}$ represent in the tables the Logit and probit models the Limit_0 and Limit_1 of values. $\gamma_{1}$ represents that point, at the NSI C of the value $(-1)$ the value $(0)$, during the derivative of NSI E, assumes. $\gamma_{2}$ represents that point, at the NSI C of the value (0) the value $(+1)$, during the derivative of NSI E, assumes.

On closer inspection of the signs (+/-) of the individual parameter estimated values the following results:

\section{CCI-Variable (Commodity Channel Index)}

With the computation of the CCI the deviation of the share prices from their statistic average values is determined. The CCI takes values between +100 and -100 . The computation of the CCI is in the chapter "technical indicators" is represented. A CCI value of over +100 shows a strong purchase behavior and a value of under -100 shows a strong sales behavior. As describes in the theoretical part, investors should buy at a high CCI value securities. Experienced investors buy at strong sales behavior and a CCI value around -100. A positive or minus sign at the CCI value changes from share to share. With the analysis of the shares listed in the table Ordered Logit and Ordered Probit of models showed up that with the shares of boron new facts Yapi, Usas, Petkim, Cimentas, Hazneder Tugla; Mardin Cimento and Kordsa at a high CCI value and with the remaining shares at a low CCI value to be bought should.

\section{OSILATOR-Variable (Stochastic Oscillator)}

The Stochastic Oscillator (SO) compares the conclusion value of a share with the observed price history within a fixed period. With rise of the prices the conclusion value of the security rises within the fixed period to its highest price level. With case of the prices the conclusion value sinks within the fixed period on its deepest price level sinks.

The Stochastic Oscillator is represented on the basis two different curves. The interpretation of the Stochastic Oscillators takes place due to a confrontation of these two curves (K\%-curve and $\mathrm{D} \%$ curve). The slowed down $\mathrm{K} \%$-curve is represented as a constant line. The slowed down $\mathrm{K} \%$-curve represents the sliding means of the $\mathrm{K} \%$-curve within a fixed period. The $\mathrm{D} \%$-curve however is dotted represented. The $\mathrm{D} \%$-curve represents the sliding means of the slowed down $\mathrm{K} \%$-curve.

The formula for the computation of the $\mathrm{K} \%$-curve reads:

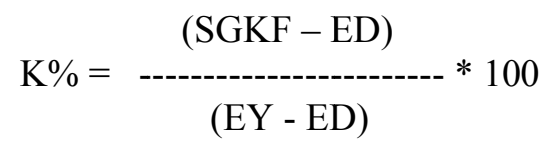

SGKF: Close value of the last daily

OD: Lowest value of the share within last five days the

EY: Maximum value of the share within the last five days 
If the conclusion value of the last daily lies in the proximity of the maximum value of the last five days, a rise of the prices is forecast and turned around. The sign of the parameter estimated value is positive $(+)$.

\section{PVT-Variable (Price-Volume-Trend)}

The regarded relationship of the prices to the acted quantity is similar to the equilibrium of the quantities and prices. With the price/quantity equilibrium becomes depending upon price rise or case, the price/quantity equilibrium of the one day lagged the up-to-date acted quantity added or taken off. With the regarded relationship of the prices to the acted quantity the acted quantity of the one day lagged cumulated a certain percentage of the up-to-date acted quantity is added or taken off. The percentage is calculated as a function of the price rise or case.

If the acted quantity rises with sinking prices, the PVT value sinks. In this situation the PVT variable shows a strong purchase behavior with low prices. Sinking prices and a sinking quantity are characteristics for one PVT value any longer not falling. From the negative connection between acted quantity and rising prices can a minus sign of the parameter estimated value (-) be derived.

\section{ROC (Price Rate of Change)}

The price adjustment rate (ROC) shows the percent change of the price of the current daily in the comparison to the price of the previous daily.

The following formula shows the computation of the price adjustment rate:

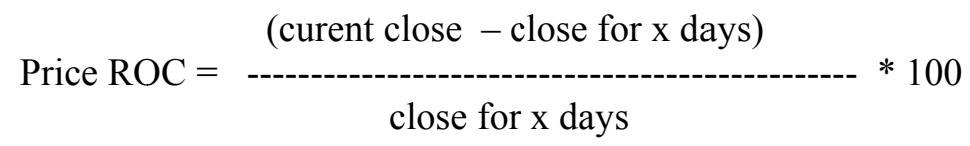

If the prices reach a point, also the ROC value reaches a point. The sign of the parameter estimated value is negative (-).

\section{VOLUME (Acted quantity)}

The acted quantity represents the quantity of the bought and sold shares. The development of the acted quantity and the prices gives important notes to future events. With sinking prices are more buyers. By the rise of the inquired quantity, the prices rise. The sign of the parameter estimated value is positive $(+)$.

The parameter estimated values of the VOLUME of indicator for the regarded shares are very small. The reason for it lies to the extent of the acted quantity. 


\section{MACD (Moving Average Convergence Divergence)}

With the help of the MACD trends can be illustrated. The MACD shows the relationship between two sliding averages, on whose basis purchase and sales decisions can be met.

With the computation of the MACD first a long-term and a short term exponentially sliding means are calculated. Subsequently, from the short term exponentially sliding means the longterm sliding means is taken off, in order to determine the MACD. If the short term exponentially sliding means is larger than the long-term exponentially sliding means, the result is positive and the MACD lies over the zero-line. This indicates a rise of the prices. If however the result is negative, the MACD is under the zero-line.

With the computation among other things the signal line is determined. This signal line results due to the values of the exponentially sliding means of the last nine days. If the MACD cuts the signal line from down up, then a purchase decision is met. If however the MACD from above cuts down the signal line, then a sales decision is met. A rising MACD value is characteristic for a rising price level. One can interpret a rising MACD value as sales signal. The sign is negative the parameter estimated value (-).

\section{MOMENTUM}

The Momentum indicates the percent change of the prices within a fixed period. With the help of the Momentum the profit or loss, which a share obtains within a certain period, can be represented. The price adjustment rate (ROC) shows a similar event as the Momentum, the difference lies in the representational form. The datum line is with the Momentum with 100 and with the ROC with 0 and on the ordinate the percent change is represented. The Momentum is computed according to the formula stated down:

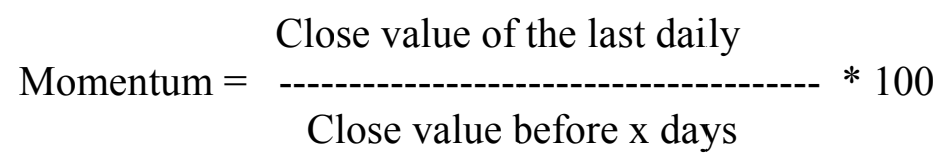

Summarized the Momentum shows the yield of a share in the comparison to the price before " $\mathrm{x}$ " days is obtained. If the Momentum a maximum value moves reached and then downward, sales decisions are met. The sign of the parameter estimated value is negative (-).

\section{RSI (Relative Strength Index)}

With the computation of this characteristic number becomes with the help of the "sliding means of the price movements upward" (MAU Moving AVERAGE UP) and the "sliding means of the price movements downward" (WAD Moving AVERAGE down) the 
development of the prices determines. The relative Strength index (RSI) curve takes a value between " 0 " and "100". Following the determination of the MAU and WAD with the help of a formula of the RSI index is determined. A rising RSI value means a sinking price history in reverse and. The sign of the parameter estimated value is negative (-).

\section{VOLOSIL (Volume Oscillator)}

The volume Oscillator (VOLOSIL) is similar to the Stochastic Oscillator. It becomes instead of for the price, for which acted quantity computes. The VOLOSIL shows the difference between the means sliding at short notice and the means of a security quantity sliding on a long-term basis. Influence parameters on the VOLOSIL represent the method of the computation of the sliding means, the Fristigkeit and the presentation method. The sign of the parameter estimated value is positive $(+)$.

\section{WILLIAMS (Williams'\% R)}

Williams ' \%R represents a Momentum indicator, by which levels are represented with multipurchases and increased sale. Williams ' $\% \mathrm{R}$ is interpreted similarly as the Stochastic Oscillator. In contrast to the Stochastic Oscillator has Williams ' $\% \mathrm{R}$ a turned sign. If Williams lies ' $\%$ R between $80 \%$ and $100 \%$, then surplus sales find with the regarded security, at a value between $0 \%$ and $20 \%$ take place surplus purchases. The purchase and sales decision should be met only if the security price moves in the reverse direction. The MACD helps with the announcement of Share - pries change. A rising Williams \% $\mathrm{R}$ marks rising prices. The sign of the parameter estimated value is positive $(+)$.

\section{NSI (-1)}

"NSI (-1)" represents the material share price adjustment of the one day lagged. If it takes the value -1 , it means that the value sank and the prices of the current daily can rise. If the "NSI (1) is" value of the one day lagged 0 or +1 , then it knows a sinking of the prices meant. The sign of the parameter estimated value is negative (-).

In the Ordered Logit and Ordered Probit models became instead of the certainty measure of $\mathrm{R}^{2}$ of the LR index (pseudo $\mathrm{R}^{2}$ ) and instead of the f-Statistic the LR Statistic used. Details in addition are in the theoretical part of this work. The pseudo $\mathrm{R}^{2}$ took very low values. This is due to the calculation method of the pseudo $\mathrm{R}^{2}$. A comparison with classical $\mathrm{R}^{2}$-values would not be correct. ${ }^{7}$

In the classical involution model the $\mathrm{R}^{2}$-value between 0 and 1 can move, whereby a value means close 1 a strong correlation. Dummy Dependent variable model does not supply value close 1 . On the assumption that in a given interval the correct probabilities of an event are

\footnotetext{
${ }^{7}$ LAITILA Thomas (1993). A pseudo-R2 measure for limited and qualitative dependent varaible models; Journal of Econometrics, 56; S:341-356
} 
evenly distributed, it is to be set it possible for $\mathrm{R}^{2}$ an upper border of. For this reason a low $\mathrm{R}^{2}$ is not unusual with the estimation of a linear probability model. ${ }^{8}$

\section{EMPRICAL RESULTS}

Following the four ISE (Istanbul Stock Exchange) indices are aforementioned the main sector indices (industry, service, financial and technology sector) and the pertinent sub sectors.

The main sector and sub sector indices cover securities, which are not acted at the stock exchange to note and at the national market.

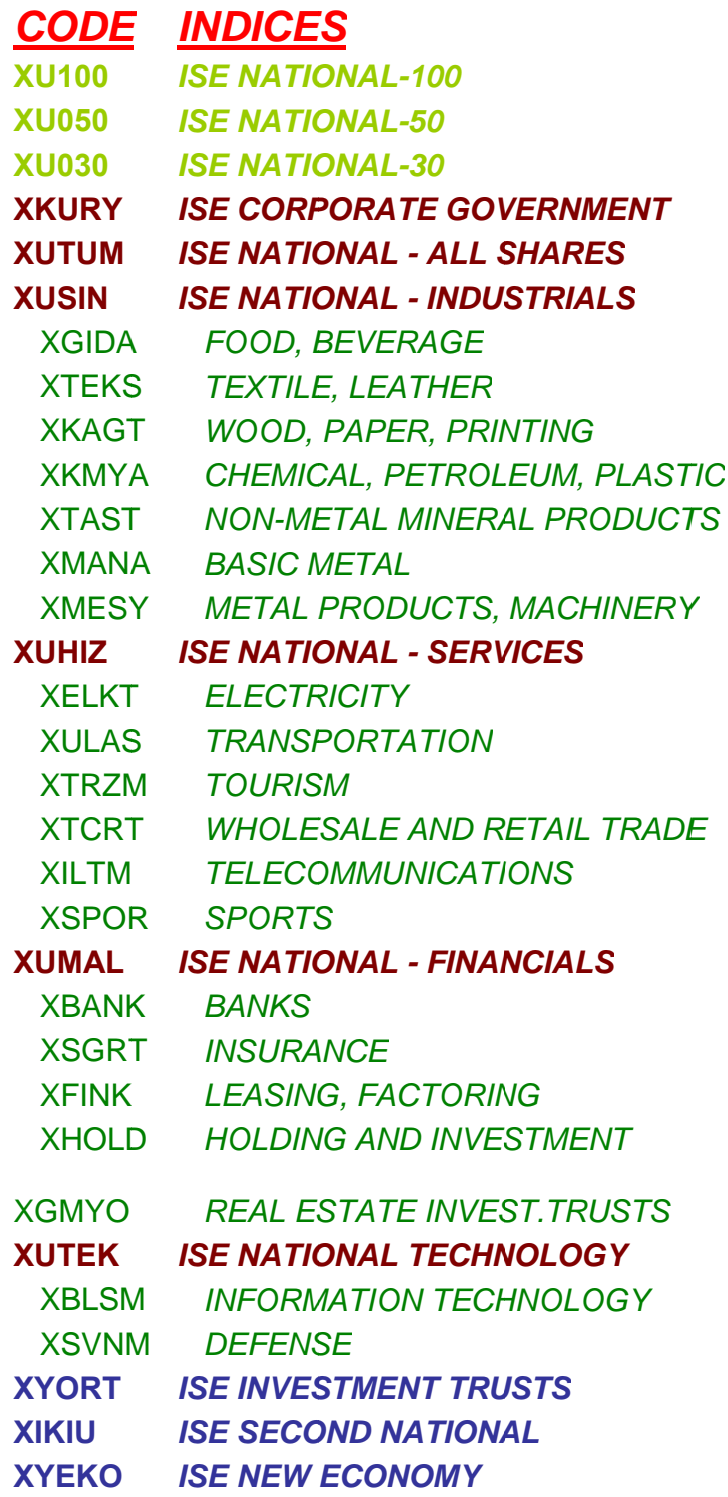

Following tables contain some of the significant parameters of variables in ordered probit models. (Table 3-4)

\footnotetext{
${ }^{8}$ PINDYCK Robert S, RUBINFELD Daniel L. (1998). Econometric models and economic forecasts; McGraw-
} Hill S. 317 


\begin{tabular}{|c|c|c|c|c|c|c|c|c|c|c|c|c|}
\hline \multirow{2}{*}{$\begin{array}{c}\text { SAMPLE } \\
\text { REGRESSION } \\
\text { OUTPUTS } \\
\end{array}$} & \multicolumn{3}{|c|}{ ABANA ELEKTRO } & \multicolumn{3}{|c|}{ AK ENERJi } & \multicolumn{3}{|c|}{ AKTAŞ ELEKTRIKK } & \multicolumn{3}{|c|}{ AYEN ENERJI } \\
\hline & & Std.Dev & Prob. & & Std.Dev & Prob. & & Std.Dev & Prob. & & Std.Dev & Prob. \\
\hline $\mathrm{N}$ & 2116 & & & 88 & & & 1585 & & & 90 & & \\
\hline \multicolumn{13}{|l|}{$\mathrm{CCl}(-1)$} \\
\hline $\begin{array}{c}\text { OSILATOR } \\
(-1)\end{array}$ & 0.01 & 0.00 & 0.00 & 0.04 & 0.02 & 0.01 & & & & & & \\
\hline \multicolumn{13}{|l|}{ PVT (-1) } \\
\hline $\operatorname{ROC}(-1)$ & -9.34 & 0.48 & 0.00 & -10.23 & 2.47 & 0.00 & -4.29 & 0.42 & 0.00 & -21.53 & 4.50 & 0.00 \\
\hline $\operatorname{VOLUME}(-1)$ & 0.00 & 0.00 & 0.04 & & & & 0.00 & 0.00 & 0.00 & & & \\
\hline $\operatorname{MACD}(-1)$ & & & & 0.00 & 0.00 & 0.00 & & & & & & \\
\hline $\begin{array}{c}\text { MOMENTUM } \\
(-1)\end{array}$ & & & & & & & -0.27 & 0.15 & 0.08 & & & \\
\hline RSI(-1) & & & & & & & & & & 0.54 & 0.25 & 0.03 \\
\hline \multicolumn{13}{|l|}{$\begin{array}{c}\text { VOLOSIL } \\
(-1)\end{array}$} \\
\hline $\begin{array}{l}\text { WILLIAMS } \\
(-1)\end{array}$ & 0.01 & 0.00 & 0.00 & 0.01 & 0.00 & 0.01 & 0.01 & 0.00 & 0.00 & 0.01 & 0.00 & 0.01 \\
\hline ISARET(-1) & -0.07 & 0.03 & 0.04 & -0.30 & 0.17 & 0.08 & -0.07 & 0.04 & 0.06 & -0.48 & 0.20 & 0.02 \\
\hline LIMIT_0 & -0.38 & 0.04 & 0.00 & -0.29 & 0.17 & 0.09 & -0.73 & 0.18 & 0.00 & 80.38 & 36.72 & 0.03 \\
\hline LIMIT_1 & 0.01 & 0.04 & 0.74 & 0.29 & 0.17 & \begin{tabular}{|l|} 
\\
\end{tabular} & -0.33 & 0.18 & 0.06 & 81.04 & 36.74 & 0.03 \\
\hline $\begin{array}{r}\text { LR index } \\
\text { (Pseudo-R2) }\end{array}$ & 0.27 & & & 0.24 & & & 0.20 & & & 0.47 & & \\
\hline $\begin{array}{c}\text { LR } \\
\text { statistic }\end{array}$ & 1134.48 & & & 42.00 & & & 648.45 & & & 79.33 & & \\
\hline $\begin{array}{l}\text { Probability } \\
\text { (LR stat) }\end{array}$ & 0.00 & & & 0.00 & & & 0.00 & & & 0.00 & & \\
\hline $\begin{array}{c}\text { HAUPT } \\
\text { SEKTOR }\end{array}$ & XUHIZ & & & XUHIZ & & & XUHIZ & & & XUHIZ & & \\
\hline $\begin{array}{c}\text { UNTER } \\
\text { SEKTOR } \\
\end{array}$ & XELKT & & & XELKT & & & XELKT & & & XELKT & & \\
\hline
\end{tabular}

Table-3: Some Of The Ordered Probit Outputs 


\begin{tabular}{|l|c|c|}
\hline & \multicolumn{1}{|c|}{$\begin{array}{c}\text { Number of } \\
\text { Efficient } \\
\text { Estimations }\end{array}$} & $\begin{array}{c}\% \text { of } \\
\text { Total }\end{array}$ \\
\hline CCI (-1) & 33 & 13.2 \\
\hline OSILATOR(-1) & 108 & 43.2 \\
\hline PVT (-1) & 58 & 23.2 \\
\hline ROC (-1) & 250 & 100 \\
\hline VOLUME(-1) & 214 & 85.6 \\
\hline MACD(-1) & 75 & 30 \\
\hline MOMENTUM(-1) & 27 & 10.8 \\
\hline RSI(-1) & 16 & 6.4 \\
\hline VOLOSIL(-1) & 49 & 19.6 \\
\hline WILLIAMS(-1) & 247 & 98.8 \\
\hline ISARET(-1) & 247 & 98.8 \\
\hline N (Mean) & \multicolumn{2}{|c|}{1642} \\
\hline $\begin{array}{l}\text { LR index (Pseudo-R2) } \\
\text { (Average) }\end{array}$ & \multicolumn{2}{|}{0.24} \\
\hline
\end{tabular}

Table-4: Summary of Models

\section{Stability of the parameter estimated values}

The stability of the estimated parameter values, in order to be able to make prognoses over the share price change, tested in the context of this work. For this from 250 shares altogether 32 shares were selected. To the criteria for choice the number of collections and the affiliation to at least a sub sector belonged. Shares with the highest collections from each sub sector each are selected. The accomplished stability test results are in the following:

With the examination of the stability of the parameter values of the selected shares at the beginning of a third of the oldest collections of the parameter computation one takes out. In a second passage finally only more half of the collections was located - which recent collections - for the order, with which a further parameter computation is accomplished. After Chow a third of the collections and afterwards half of the collections are taken out last of the center of the entire elevations. Those only with the oldest and recent collections the parameter values are computed. The estimated parameter values with the full collection number are compared after that far method with the estimated parameter values, represented down, with smaller collections and their stability is tested.

$$
\begin{aligned}
& H_{0}=\hat{\beta}=\beta_{0} \\
& H_{1}=\hat{\beta} \neq \beta_{0}
\end{aligned}
$$

A t-test was accomplished: $t_{\text {stat }}=\frac{\hat{\beta}-\beta_{0}}{S_{\hat{\beta}}}$

By the fulfillment of the condition $\mathrm{t}_{\text {stat }}<\mathrm{t}_{\text {table }}$ the $\mathrm{H}_{0}$ hypothesis is not rejected and the stability of the estimated parameter values of the regarded 32 shares was confirmed. 
The estimated parameter values and stability test determined for the selected 32 shares are in the appendix. The results displays that the change of the number of collections do not cause statistic change of the estimated parameter values.

\section{CONCLUSION}

In summary we can say that during the derivative of NSI E: NSI C the value (-1) assumes, if it smaller as if is. NSI C takes the value (0), if it lies between and. NSI C takes the value $(+1)$, if it more largely as if is.

For all technical indicators with the computation of the variables one day lagged values are used. The conclusion values of 250 shares are raised for the calculations of the technical indicators. The technical indicators as argument were used for the determination of the parameter values, thereby altogether 250 models are set up. It participated interesting that the estimated parameter values of the 250 shares were close. For 33 models the CCI variable, for 108 models the OSILATOR variable, is efficient for 58 models the PVT variable, for all models the ROC variable, for 214 models the volume variable, for 75 models the MACD variable, for 27 models the moment around variable, for 16 models the RSI variable, for 49 models the volume OS IL variable, for 247 models the WILLIAMS variable and for 247 models the NSI(-1) variable.

With those models, in which the technical indicators represent the arguments, Turkcell, Anadolu Efes and Ayen Enerji had extreme parameter values. Since the number of collections is very small with these shares, one can meet the acceptance that iterated parameter values are not reached.

\section{Model prognoses}

With above the 32 shares select for the stability test of the estimated parameter values prognoses become for one period of three months (10 October to 24. January 2007) accomplished. With these prognoses the "NSI R" (NSI calculated) of values is determined and derived from these the "NSI E" (NSI estimated). The derived "NSI E" of values is compared afterwards with the "NSI R" (NSI real) values.

Point prognoses and interval prognoses are accomplished. In the context of the point prognosis "NSI C" of values determined with the Limit_0 and Limit_1 is compared and from it "NSI E" derived. "NSI C" was under Limit_0 to "NSI P" on (-1) is then specified. With a "NSI C" between Limit_0 and Limit_1 "NSI $\overline{\mathrm{E}}$ " is specified on $(0)$ and with a "NSI C" over Limit_1 on (+1). After derivative of "NSI E" it is compared with "NSI R" and prognosis accuracy is determined. In the case of the point prognoses resulted is prognosis accuracy between 54 to 72 per cent.

For the execution of the interval prognoses additionally still the "NSI becomes CU" value (NSI calculated lower one limit) and "the NSI CO" value (NSI calculated upper one border) determines. With the help of these two limit values, as during the derivative of the "NSI E", the "NSI of EU" values (NSI prognosticated lower ones limit) and "NSI of EO" values (NSI prognosticated upper one border) is derived. It was checked whether the "NSI R"-value is 
within these two values - between "NSI EU" and "NSI PO" -. With the regarded 32 models (ever a model per share)"NSI R" is observed within these interval values with a frequency from 70 to 96 per cent.

The intervals - "NSI EU" and "NSI EO" - failed sometimes very closely and again very broadly. With very close intervals (ex.: "NSI EU" $=+1$ and "NSI EO" $=+1$ )"NSI E" can speak with the interval borders of safe prognoses with agreement of the point prognosis. Being on the other side the interval borders far apart ("NSI EU" $=-1$ and "NSI EO" $=+1$ ) cannot be made safe statements about the point prognosis "NSI E". The reason for the far interval borders lies in the high standard deviation and the Limit_0 and Limit_1 values, for which again external factors of influence, lying apart far, as speculation behavior is responsible.

With the regarded 32 shares one could observe interval width of "NSI EU" within the observed period of 3 months $=-1$ to "NSI EO" $=+1$ between 9 per cent and 83 per cent. From it an average value of 57,4 per cent for 32 shares results. "NSI EU" $=+1$ to "NSI EO" $=+1$ was observed with the 32 shares within the period by 3 months with a frequency from 5,5 to 62.5 per cent, results in an average value of 20,1 per cent. When agreeing the "NSI E", "NSI EU" and "NSI EO" values an agreement with "NSI R" is determined between 61 and 100 per cent, i.e. with an average value of 89 per cent.

In principle one can say that with all securities with $18(=0.201 * 0.89)$ of per cent probability safe prognoses can be accomplished. Summarized we can say that one with 63 per cent of correct point prognoses altogether with approx.. 57 per cent of all prognoses about no safe prognoses to talk can lie apart, there the interval borders far and with approx.. 18 per cent about safe prognoses to talk can lie apart. With the remaining 25 per cent can be statements about the point prognoses as well as the intervals made. (Table 5) 


\begin{tabular}{|c|c|c|c|c|c|c|}
\hline Stock & & $\begin{array}{c}\text { NSI E } \\
\text { Correct }\end{array}$ & $\begin{array}{c}\text { Interval } \\
\text { Estimation } \\
\text { Correct }\end{array}$ & $\begin{array}{c}\text { NSI E }=\text { NSI EU }=\text { NSI } \\
\text { EO }\end{array}$ & $\begin{array}{l}\text { NSI E }= \\
\text { NSI EU } \\
= \\
\text { NSI EO } \\
\text { Correct }\end{array}$ & $\begin{array}{c}\text { NSI PU }=- \\
1 \\
\text { NSI } \\
\text { PO=+1 } \\
\text { NSI P } \\
\text { Betwixt }\end{array}$ \\
\hline İş BANKASI (C) & $\begin{array}{c}\text { Amount } \\
\text { in } \%\end{array}$ & $\begin{array}{c}43 \\
60.56 \\
\end{array}$ & $\begin{array}{c}\mathbf{6 7} \\
94.37 \\
\end{array}$ & $\begin{array}{c}\mathbf{1 3} \\
18.31 \\
\end{array}$ & $\begin{array}{c}11 \\
84.62 \\
\end{array}$ & $\begin{array}{c}\mathbf{4 3} \\
60.56 \\
\end{array}$ \\
\hline YAPI VE KREDİ BANK. & $\begin{array}{c}\text { Amount } \\
\text { in } \%\end{array}$ & $\begin{array}{c}\mathbf{4 6} \\
64.79\end{array}$ & $\begin{array}{c}\mathbf{6 7} \\
94.37\end{array}$ & $\begin{array}{c}\mathbf{1 7} \\
23.94\end{array}$ & $\begin{array}{c}\mathbf{1 5} \\
88.24\end{array}$ & $\begin{array}{c}35 \\
49.30\end{array}$ \\
\hline İKTISAT FIN. KİR. & $\begin{array}{c}\text { Amount } \\
\text { in } \%\end{array}$ & $\begin{array}{c}42 \\
59.15\end{array}$ & $\begin{array}{c}\mathbf{6 6} \\
92.96 \\
\end{array}$ & $\begin{array}{c}\mathbf{1 6} \\
22.54 \\
\end{array}$ & $\begin{array}{c}\mathbf{1 4} \\
87.50\end{array}$ & $\begin{array}{c}37 \\
52.11\end{array}$ \\
\hline VAKIF GMYO & $\begin{array}{c}\text { Amount } \\
\text { in \% }\end{array}$ & $\begin{array}{c}39 \\
57.35 \\
\end{array}$ & \begin{tabular}{|c|}
$\mathbf{6 4}$ \\
94.12 \\
\end{tabular} & $\begin{array}{c}\mathbf{8} \\
11.76 \\
\end{array}$ & $\begin{array}{c}\mathbf{6} \\
75.00 \\
\end{array}$ & $\begin{array}{c}\mathbf{4 8} \\
70.59 \\
\end{array}$ \\
\hline ALARKO HOLDING & $\begin{array}{c}\text { Amount } \\
\text { in } \%\end{array}$ & $\begin{array}{c}43 \\
60.56 \\
\end{array}$ & $\begin{array}{c}\mathbf{6 6} \\
92.96 \\
\end{array}$ & $\begin{array}{c}\mathbf{1 8} \\
25.35 \\
\end{array}$ & $\begin{array}{c}\mathbf{1 6} \\
88.89 \\
\end{array}$ & $\begin{array}{c}37 \\
52.11 \\
\end{array}$ \\
\hline ENKA HOLDİNG & $\begin{array}{c}\text { Amount } \\
\text { in } \%\end{array}$ & $\begin{array}{c}\mathbf{5 6} \\
72.73 \\
\end{array}$ & $\begin{array}{c}76 \\
98.70\end{array}$ & $\begin{array}{c}\mathbf{1 2} \\
15.58\end{array}$ & $\begin{array}{c}11 \\
91.67\end{array}$ & $\begin{array}{c}\mathbf{5 3} \\
68.83 \\
\end{array}$ \\
\hline KOÇ HOLDING & $\begin{array}{c}\text { Amount } \\
\text { in } \%\end{array}$ & $\begin{array}{c}1 \\
56.94\end{array}$ & $\begin{array}{c}\mathbf{6 9} \\
95.83\end{array}$ & $\begin{array}{c}17 \\
23.61\end{array}$ & $\begin{array}{c}\mathbf{1 4} \\
82.35\end{array}$ & $\begin{array}{c}\mathbf{3 8} \\
52.78\end{array}$ \\
\hline ANADOLU SIGGORTA & $\begin{array}{c}\text { Amount } \\
\text { in } \% \\
\end{array}$ & \begin{tabular}{|c|}
39 \\
54.17 \\
\end{tabular} & $\begin{array}{c}\mathbf{5 1} \\
70.83 \\
\end{array}$ & $\begin{array}{c}\mathbf{4 5} \\
62.50 \\
\end{array}$ & $\begin{array}{r}\mathbf{3 7} \\
82.22 \\
\end{array}$ & $\begin{array}{c}7 \\
9.72 \\
\end{array}$ \\
\hline ANADOLU GIDA & $\begin{array}{c}\text { Amount } \\
\text { in \% }\end{array}$ & \begin{tabular}{|c|}
45 \\
65.22 \\
\end{tabular} & $\begin{array}{c}\mathbf{6 7} \\
97.10 \\
\end{array}$ & $\begin{array}{c}\mathbf{1 3} \\
18.84 \\
\end{array}$ & $\begin{array}{c}\mathbf{8} \\
61.54 \\
\end{array}$ & $\begin{array}{c}\mathbf{3 9} \\
56.52 \\
\end{array}$ \\
\hline MARET & $\begin{array}{c}\text { Amount } \\
\text { in } \%\end{array}$ & $\begin{array}{c}47 \\
65.28\end{array}$ & $\begin{array}{c}71 \\
98.61\end{array}$ & $\begin{array}{c}\mathbf{1 7} \\
23.61\end{array}$ & $\begin{array}{c}\mathbf{1 6} \\
94.12 \\
\end{array}$ & $\begin{array}{c}\mathbf{3 4} \\
47.22 \\
\end{array}$ \\
\hline PINAR SU & $\begin{array}{c}\text { Amount } \\
\text { in } \%\end{array}$ & $\begin{array}{c}\mathbf{5 0} \\
69.44 \\
\end{array}$ & $\begin{array}{c}\mathbf{7 1} \\
98.61 \\
\end{array}$ & $\begin{array}{c}\mathbf{5} \\
6.94 \\
\end{array}$ & $\begin{array}{c}\mathbf{4} \\
80.00 \\
\end{array}$ & $\begin{array}{c}\mathbf{6 0} \\
83.33 \\
\end{array}$ \\
\hline AYGAZ & $\begin{array}{c}\text { Amount } \\
\text { in } \% \\
\end{array}$ & \begin{tabular}{|c|}
45 \\
62.50 \\
\end{tabular} & $\begin{array}{c}\mathbf{7 0} \\
97.22 \\
\end{array}$ & $\begin{array}{c}\mathbf{1 1} \\
15.28 \\
\end{array}$ & \begin{tabular}{|c|}
$\mathbf{1 0}$ \\
90.91 \\
\end{tabular} & \begin{tabular}{|c|}
$\mathbf{3 8}$ \\
52.78 \\
\end{tabular} \\
\hline BRISA & $\begin{array}{c}\text { Amount } \\
\text { in } \%\end{array}$ & \begin{tabular}{|c|}
$\mathbf{4 4}$ \\
62.86 \\
\end{tabular} & \begin{tabular}{|c|}
$\mathbf{6 6}$ \\
94.29 \\
\end{tabular} & $\begin{array}{c}\mathbf{2 2} \\
31.43 \\
\end{array}$ & $\begin{array}{c}\mathbf{1 8} \\
81.82 \\
\end{array}$ & \begin{tabular}{|c|}
$\mathbf{3 6}$ \\
51.43 \\
\end{tabular} \\
\hline ECZACIBAŞI İLAÇ & $\begin{array}{c}\text { Amount } \\
\text { in } \% \\
\end{array}$ & \begin{tabular}{|c|}
$\mathbf{4 9}$ \\
69.01 \\
\end{tabular} & $\begin{array}{c}\mathbf{7 1} \\
100.00 \\
\end{array}$ & \begin{tabular}{|c}
$\mathbf{1 5}$ \\
21.13 \\
\end{tabular} & $\begin{array}{c}\mathbf{1 5} \\
100.00 \\
\end{array}$ & \begin{tabular}{|c}
$\mathbf{5 6}$ \\
78.87 \\
\end{tabular} \\
\hline PETKIM & $\begin{array}{c}\text { Amount } \\
\text { in } \%\end{array}$ & $\begin{array}{c}\mathbf{4 4} \\
61.11 \\
\end{array}$ & $\begin{array}{c}\mathbf{7 0} \\
97.22 \\
\end{array}$ & $\begin{array}{c}\mathbf{1 4} \\
19.44 \\
\end{array}$ & $\begin{array}{c}\mathbf{1 4} \\
100.00 \\
\end{array}$ & $\begin{array}{c}\mathbf{4 3} \\
59.72 \\
\end{array}$ \\
\hline ÇELİK HALAT & $\begin{array}{c}\text { Amount } \\
\text { in } \% \\
\end{array}$ & \begin{tabular}{|c|}
$\mathbf{4 6}$ \\
63.89 \\
\end{tabular} & $\begin{array}{c}\mathbf{7 2} \\
100.00 \\
\end{array}$ & $\begin{array}{c}\mathbf{8} \\
11.11 \\
\end{array}$ & $\begin{array}{c}\mathbf{8} \\
100.00 \\
\end{array}$ & $\begin{array}{c}49 \\
68.06 \\
\end{array}$ \\
\hline EREĞLİ DEMİR CELİK & $\begin{array}{c}\text { Amount } \\
\text { in } \%\end{array}$ & $\begin{array}{c}\mathbf{5 2} \\
72.22 \\
\end{array}$ & \begin{tabular}{|c|}
$\mathbf{7 0}$ \\
97.22 \\
\end{tabular} & $\begin{array}{c}\mathbf{1 3} \\
18.06 \\
\end{array}$ & $\begin{array}{c}\mathbf{1 2} \\
92.31 \\
\end{array}$ & \begin{tabular}{|c|}
$\mathbf{4 2}$ \\
58.33 \\
\end{tabular} \\
\hline SARKUYSAN & $\begin{array}{c}\text { Amount } \\
\text { in } \%\end{array}$ & $\begin{array}{c}\mathbf{5 1} \\
70.83 \\
\end{array}$ & $\begin{array}{c}\mathbf{6 8} \\
94.44 \\
\end{array}$ & $\begin{array}{c}\mathbf{1 2} \\
16.67 \\
\end{array}$ & $\begin{array}{c}\mathbf{1 2} \\
100.00 \\
\end{array}$ & $\begin{array}{c}\mathbf{3 7} \\
51.39 \\
\end{array}$ \\
\hline ARÇELIK & $\begin{array}{c}\text { Amount } \\
\text { in } \% \\
\end{array}$ & $\begin{array}{c}45 \\
62.50 \\
\end{array}$ & \begin{tabular}{|c|}
$\mathbf{6 8}$ \\
94.44 \\
\end{tabular} & \begin{tabular}{|c|}
19 \\
26.39 \\
\end{tabular} & $\begin{array}{c}\mathbf{1 6} \\
84.21 \\
\end{array}$ & $\begin{array}{c}\mathbf{4 2} \\
58.33 \\
\end{array}$ \\
\hline MAKINA TAKIM & $\begin{array}{c}\text { Amount } \\
\text { in } \%\end{array}$ & \begin{tabular}{|c|}
$\mathbf{3 9}$ \\
54.17 \\
\end{tabular} & \begin{tabular}{|c|}
$\mathbf{6 6}$ \\
91.67 \\
\end{tabular} & \begin{tabular}{|c|}
$\mathbf{1 5}$ \\
20.83 \\
\end{tabular} & $\begin{array}{c}\mathbf{1 1} \\
73.33 \\
\end{array}$ & $\begin{array}{c}\mathbf{4 4} \\
61.11 \\
\end{array}$ \\
\hline T.DEMIIR DÖKÜM & $\begin{array}{c}\text { Amount } \\
\text { in } \%\end{array}$ & $\begin{array}{c}47 \\
65.28 \\
\end{array}$ & $\begin{array}{c}\mathbf{7 1} \\
98.61 \\
\end{array}$ & $\begin{array}{c}\mathbf{8} \\
11.11 \\
\end{array}$ & $\begin{array}{c}7 \\
87.50 \\
\end{array}$ & $\begin{array}{c}\mathbf{4 7} \\
65.28 \\
\end{array}$ \\
\hline ÇíMSA & $\begin{array}{c}\text { Amount } \\
\text { in } \%\end{array}$ & $\begin{array}{c}\mathbf{4 4} \\
61.11 \\
\end{array}$ & $\begin{array}{c}\mathbf{7 1} \\
98.61 \\
\end{array}$ & $\begin{array}{c}\mathbf{1 4} \\
19.44 \\
\end{array}$ & \begin{tabular}{|c|}
$\mathbf{1 3}$ \\
92.86 \\
\end{tabular} & \begin{tabular}{|c|}
$\mathbf{4 3}$ \\
59.72 \\
\end{tabular} \\
\hline İZOCAM & $\begin{array}{c}\text { Amount } \\
\text { in } \%\end{array}$ & $\begin{array}{c}43 \\
59.72 \\
\end{array}$ & $\begin{array}{c}71 \\
98.61 \\
\end{array}$ & $\begin{array}{c}\mathbf{9} \\
12.50 \\
\end{array}$ & $\begin{array}{c}\mathbf{8} \\
88.89 \\
\end{array}$ & $\begin{array}{c}41 \\
56.94 \\
\end{array}$ \\
\hline
\end{tabular}




\begin{tabular}{|l|c|c|c|c|c|c|} 
& Amount & $\mathbf{4 0}$ & $\mathbf{6 8}$ & $\mathbf{1 8}$ & $\mathbf{1 6}$ & $\mathbf{3 3}$ \\
& in \% & 55.56 & 94.44 & 25.00 & 88.89 & 45.83 \\
\hline AKAL TEKSTİL & Amount & $\mathbf{4 4}$ & $\mathbf{7 0}$ & $\mathbf{1 3}$ & $\mathbf{1 2}$ & $\mathbf{4 0}$ \\
& in \% & 61.11 & 97.22 & 18.06 & 92.31 & 55.56 \\
\hline KORDSA SABANCI DUPONT & Amount & $\mathbf{5 4}$ & $\mathbf{6 9}$ & $\mathbf{1 8}$ & $\mathbf{1 7}$ & $\mathbf{3 7}$ \\
& in \% & 75.00 & 95.83 & 25.00 & 94.44 & 51.39 \\
\hline YÜNSA & Amount & $\mathbf{4 2}$ & $\mathbf{7 0}$ & $\mathbf{9}$ & $\mathbf{8}$ & $\mathbf{4 0}$ \\
& in \% & 58.33 & 97.22 & 12.50 & 88.89 & 55.56 \\
\hline GENTAŞ & Amount & $\mathbf{5 1}$ & $\mathbf{7 2}$ & $\mathbf{1 5}$ & $\mathbf{1 5}$ & $\mathbf{4 3}$ \\
& in \% & 70.83 & 100.00 & 20.83 & 100.00 & 59.72 \\
\hline KARTONSAN & Amount & $\mathbf{4 0}$ & $\mathbf{7 0}$ & $\mathbf{4}$ & $\mathbf{3}$ & $\mathbf{5 3}$ \\
& in \% & 55.56 & 97.22 & 5.56 & 75.00 & 73.61 \\
\hline HÜRRIYET GZT. & Amount & $\mathbf{4 7}$ & $\mathbf{7 2}$ & $\mathbf{8}$ & $\mathbf{8}$ & $\mathbf{4 9}$ \\
& in \% & 65.28 & 100.00 & 11.11 & 100.00 & 68.06 \\
\hline ALCATEL TELETAŞ & Amount & $\mathbf{5 0}$ & $\mathbf{7 0}$ & $\mathbf{2 1}$ & $\mathbf{1 9}$ & $\mathbf{3 9}$ \\
& in \% & 69.44 & 97.22 & 29.17 & 90.48 & 54.17 \\
\hline ASELSAN & Amount & $\mathbf{4 6}$ & $\mathbf{7 1}$ & $\mathbf{1 5}$ & $\mathbf{1 5}$ & $\mathbf{4 2}$ \\
& in \% & 63.89 & 98.61 & 20.83 & 100.00 & 58.33 \\
\hline
\end{tabular}

Table-5: Point and interval prognoses 


\section{REFERENCES}

- ACHELIS Steven B. (2001). Technical Analysis from A to Z; http://www.equis.com/free/taaz/.

- ALDRICH John H. and NELSON Forrest D. (1985). Linear Probability, Logit, and Probit Models; Sage University Papers No: 07-045.

- BACKHAUS Klaus (2000). Multivariate Analysemethoden; Springer.

- BACKUS, David (1998). Discrete-time models of bond pricing; National Bureau of Economic Research, Working paper series / 6736.

- BAUER Richard J. and DAHLQUIST Julie R. (1999). Technical market indicators: analysis \& performance; Wiley.

- BELARMINO Andenso-Diaz and FERNANDO Gascon (1997). Linking Weighting Efficiency Estimates with Stock Performance in Banking Firms; The Wharton School Financial Institutions Center.

- CAMPBELL John Y., LO Andrew W. and MACKInLAY A. Craig (1997). The econometrics of financial markets; Princeton Univ. Press.

- CARMAN Peter (1997). Quantitative investing for the global markets: strategies, tactics and advanced analytical techniques; Glenlake Publ. Co.

- CHIRISTOFFERSEN Peter F. and FRANCIS X. Diebold (1997). How Relevant is Volatility Forecasting for Financial Risk Management? The Wharton School Financial Institutions Center.

- COLBY Robert W. and MEYERS Thomas A. (1988). 7th Encyclopedia of Technical Market Indicators; Dow Jones-Irwin.

- DAGANZO Carlos F (1991). Logistics systems analysis; Springer.

- FOCARDI, Sergio and JONAS, Caroline (1997). Modeling the market; Fabozzi Assoc.

- FRECKA Thomas J. and LEE Cheng F. (1983). A Seemingly Unrelated Regressions Aproach to Analysing and Forecasting Financial Ratios; Journal of Economics and Business 35, 379-388.

- FRONE R. Michael (1997). Regression Models for Discrete and Limited Dependent Variables; Pace University Research Methods Forum.

- FULLER Russell J. , FARRELL James L. and WODERN Jr. (1987). Investments and Security Analysis; McGraw Hill.

- GILCHRIST Simon and HIMMELBERG Charles (1998). Investment, Fundamentals and Finance; NBER Working Paper No. W6652.

- GOURIEROUX Christian (2000). Econometrics of Qualitative Dependent Variables; Cambridge University Press.

- GRAY Cherly W. and LINN J.F. (1988). Improving Public Finance for Development; Finance, Development, Sep.

- GREENE, William H. (2000). Econometric analysis; Prentice Hall.

- IMKB (2001). http://www.imkb.gov.tr/endeksler.htm; .

- JOHNSON, Norman Lloyd (1997). Discrete multivariate distributions; Wiley.

- JOSEPH E., MURPHY Jr. (1994). Stock Market Probability: Using Statistics to Predict and Optimize Investment Outcomes, Revised Edition; Irwin.

- KALLUNKI Juha-Pekka, TEPPO Martikainen and JUKKA Parttunen (1996). The Proportionality of Financial Ratios: Implications for Ratio Classifications; AppliedFinancial-Economics 6(6).

- KEITH P.K., JONHSON GL. and SMITH R.E. (1975). Inflation cases Common Stocks; Financial Analyst Journal, Feb. 
- KERAN Michael W. (1977). Expectations, Money and the Stock Market; Review; Federal Reserve Bank of St. Louis Jänner.

- KIEFER Nicholas M. (1997). Financial Econometrics Market Microstructure Models; Istanbul Stok Exchange.

- LAITILA Thomas (1993). A pseudo-R2 measure for limited and qualitative dependent varaible models; Journal of Econometrics, 56.

- LO Andrew W. und MAMAYSKY Harry and WANG Jiang (2000). Founddations of Technical Analysis: Computational Algoruthms, Statistical inference, and Emprical Implementation; NBER Working Paper: 7613.

- MOORE G.H. and CULLITY J.P. (1988). Security Markets and Business Cycles, The Financial Analysts Handbook; Dow Jones-Irwin.

- NAGEL H. and HATZINGER R. (1990). Diagnostics in some discrete choice models; Forschungbericht Wirtschafts Universität Wien Institut für Statistik.

- PAAP Richard and FRANSES Philip Hans (2000). Adynamic Multinomial Probit Model for Brand Choice with Different Long-Run and Short-Run Effects of Marketing-Mix Variables; Journal of Applied Econometrics, 15.

- PLUMMER Tony and WILliAM F. (1991). Forecasting Financial Markets: Technical Analysis and the Dynamics of Price; Wiley.

- PYNDICK R. and SOLIMANO A. (1993). Economic Instability and Aggregate Investment; NBER Macroeconomics Annual.

- STINEBRICKNER Todd R. (2000). Serially Correlated Variables in Dynamic Discrete Choice Models; Journal of Applied Econometrics, 15.

- SUMER, K. K. (2006). White'in Heteroskedisite Tutarli Kovaryans Matrisi Tahmini Yoluyla Heteroskedisite Altinda Model Tahmini. Istanbul University Econometrics and Statistics e-Journal, 4(1), 17-24.

- SUMER, K. K. (2013). An Early Warning Model with Technical Indicators: The Case of ISE (Istanbul Stock Exchange).

- ZELTEMAN Daniel (1999). Models for discrete data; Oxford science publications. 